\title{
Development of ARMS PCR tests for detection of common CFTR gene mutations
}

\author{
O. O. Soloviov, V. M. Pampukha, L. A. Livshits
}

Institute of Molecular Biology and Genetics NAS of Ukraine 150, Akademika Zabolotnoho Str., Kyiv, Ukraine, 03680

livshits@imbg.org.ua

\begin{abstract}
Aim. To develop diagnostic assays, based on the amplification refractory mutation system (ARMS) principle, for detection of common mutations in the CFTR gene using two approaches: standard PCR with further gel-electrophoresis and Real-Time PCR with SYBR Green. Materials. For this study we have chosen the following mutations: dF508, W1282X, R117H, 621 + 1G>T,2143delT with the frequencies in Ukraine: dF508-43.3\%; 2143 delT $-1.38 \%$; W1282X-1.1\%; R117H, $621+1 G>T-<0.6 \%$. For the development and validation of the assay we have used control DNA samples with abovementioned mutations, which were previously examined using RFLP and heteroduplex analysis. Results. We have designed the primers and optimized the conditions of ARMS PCR performing for the analysis of dF508, W1282X, R117H, $621+1 G>T, 2143$ delT mutations. To validate the developed assays we have analyzed control DNA samples with the following mutations: W1282X $(n=3), R 117 \mathrm{H}(n=2), 621+1 G>T(n=1), 2143 \operatorname{delT}(n=$ $=1)$. For validation of the dF508 assay we have analyzed 100 heterozygous carriers and 50 homozygous carriers. We have analyzed 48 patients with cystic fibrosis, in which only one mutation was previously detected in combination with unknown mutant variant, using the developed ARMS assay for the 2143 delT mutation, and detected 4 heterozygous carriers. No differences were observed in comparison with the standard protocols. Conclusions. It was shown that ARMS is a reliable, rapid and inexpensive method, and the developed assays can be applied in the standard PCR protocol with further gel-electrophoresis as well as using Real-Time PCR with SYBR Green for the molecular genetic diagnostics of cystic fibrosis.
\end{abstract}

Keywords: ARMS, Real-Time PCR, cystic fibrosis, CFTR gene.

Introduction. Cystic fibrosis (CF) is one of the most common autosomal-recessive disorders in Caucasians that occurs with the frequency of $1 / 2500$ newborns and is caused by mutations in the CFTR gene. More than 1700 mutations were identified in this gene and the dF508 deletion was described as a causative mutation $[1,2]$. A number of methods are applied for molecular genetic diagnostics of CF, namely, RFLP, SSCP, DGGE, dHPLC etc., but they are relatively slow and technically demanding.

Several independent groups described a PCR-based approach for analyzing known point mutations in

(C) Institute of Molecular Biology and Genetics NAS of Ukraine, 2010
DNA and distinguishing between the normal, heterozygous and homozygous mutant genotypes. This method is commonly referred to as PCR-ARMS or ARMS (amplification refractory mutation system). ARMS is based on the observation that PCR amplification is inefficient or completely refractory if there is a mismatch between the 3 ' terminal nucleotide of a PCR primer and a corresponding template [3-5].

This approach implies two PCR reactions. Amplification of the normal allele is accomplished using a primer complementary to the normal allele. Conversely, only the mutant allele will be amplified if the 3 ' residue is complementary to the mutant sequence. Thus, as a result a normal individual generates PCR product 


\begin{tabular}{|c|c|c|}
\hline Mutation & Nucleotide sequence & Amplicon size, bp \\
\hline \multirow[t]{3}{*}{$\mathrm{dF} 508$} & GCCTGGCACCATTAAAGAA - common & 80 \\
\hline & GTATCTATATTCATCATAGGAAACACCACA - wild type & \\
\hline & GTATCTATATTCATCATAGGAAACACCATT - mutant & \\
\hline \multirow{2}{*}{$\mathrm{R} 117 \mathrm{H}$} & CCTATGCCTAGATAAATCGCGATAGAAC - wild type & \\
\hline & CCTATGCCTAGATAAATCGCGATAGAAT - mutant & \\
\hline $621+1 \mathrm{G}>\mathrm{T}$ & TGCCTTCTCTTTATTGTGAGGACACT - common & 138 \\
\hline \multirow[t]{3}{*}{ W1282X } & CCCATCACTTTTACCTTATAGGTGGGCCTC - common & 178 \\
\hline & CCTGTGGTATCACTCCAAAGGCTTTCCAC - wild type & \\
\hline & CCTGTGGTATCACTCCAAAGGCTTTCCAT - mutant & \\
\hline \multirow[t]{3}{*}{2143 delT } & ATGGGATGTGATTCTTTCGA - common & 81 \\
\hline & GAGACCTTACACCGTTTCTCATTA - wild type & \\
\hline & GAGACCTTACACCGTTTCTCATAG - mutant & \\
\hline
\end{tabular}

only in the normal reaction; a heterozygote gives products in both reactions, and a homozygous mutant individual gives amplification only in the mutant reaction [6].

This method has many advantages over the traditional methods of mutation detection: it is rapid (the analysis is done in $2-3$ hours), inexpensive, reliable when a positive control sample is used, and it can be easily visualized not only by electrophoresis in agarose gel but also by means of Real-Time PCR system. However, the ARMS method depends on several factors: proper primers design and optimization of PCR conditions to avoid nonspecific amplification of the nor$\mathrm{mal} /$ mutant allele that could bring to false positive or negative results $[6,7]$.

Our aim was to develop ARMS methods for the analysis of common mutations causing $\mathrm{CF}$, using both general PCR with the agarose gel electrophoresis system and Real-Time PCR assay as a prototype of the test kits for molecular genetic diagnostics of CF. For our study we have chosen the following mutations: dF508, W1282X, R117H, $621+1 \mathrm{G}>\mathrm{T}, 2143$ delT. We have calculated the frequencies of these mutations in Ukrai- ne as dF508 - 43.3\%; 2143delT - $1.38 \%$; W1282X $1.1 \%$; $117 \mathrm{H}, 621+\mathrm{G}>\mathrm{T}-<0,6 \%$.

Materials and methods. DNA extraction. DNA was extracted from peripheral blood leukocytes by standard phenol-chloroform extraction methods [9].

ARMS primers and conditions. ARMS PCR amplification of the dF508, W1282X, R117H, 621 + 1G > T and 2143 delT mutations was performed with using specific oligonucleotide primers complementary either to the wild type sequence, or the DNA with mutation (Table).

The PCR reaction was performed in a final volume of $15 \mu \mathrm{l}$ containing $1 \times$ PCR buffer, $1.5 \mathrm{mM} \mathrm{MgCl}_{2}$, $200 \mu \mathrm{M}$ of each dNTP, 0.2 units of Taq-DNA polymerase (Biolabtech company) and 50-200 ng of the DNA template.

The Real-Time PCR was performed in a final volume of $15 \mu \mathrm{l}$ containing $1 \times$ PCR buffer, $1.5 \mathrm{mM}$ $\mathrm{MgCl}_{2}, 200 \mu \mathrm{M}$ of each dNTP, 0.2 units of Taq-DNA polymerase (Biolabtech company), $1 \mu \mathrm{l} 2 \times$ SYBR Green and 25-50 ng of the DNA template.

The control DNA samples with the dF508, W1282X, R117H, 621 + 1G > T, 2143delT mutations 
$A$

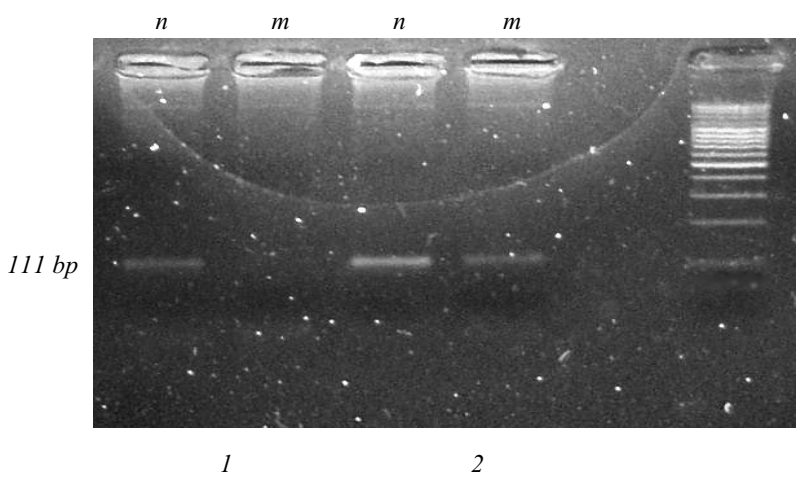

$B$

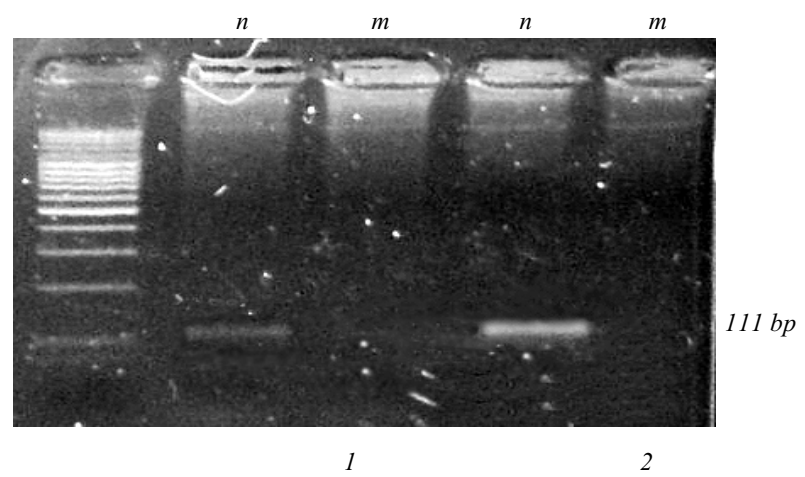

Fig. 1. Electrophoregram for the analysis of a single ARMS assay for the R117H mutation in exon 4 of the $C F T R$ gene of the wild type samples; $1.8 \%$ agarose gel. The first lanes $(n)$ of each sample are the products with normal set of primers and the second lanes $(m)-$ amplification products with mutant set of primers. The results with the concentration of primers $5 \mathrm{pM}(A)$ show that the sample 1 corresponds to heterozygous carrier of the $\mathrm{R} 117 \mathrm{H}$ mutation. Reducing the concentration of primers to $2.5 \mu \mathrm{M}(B)$ eliminates nonspecific amplification of the mutant product
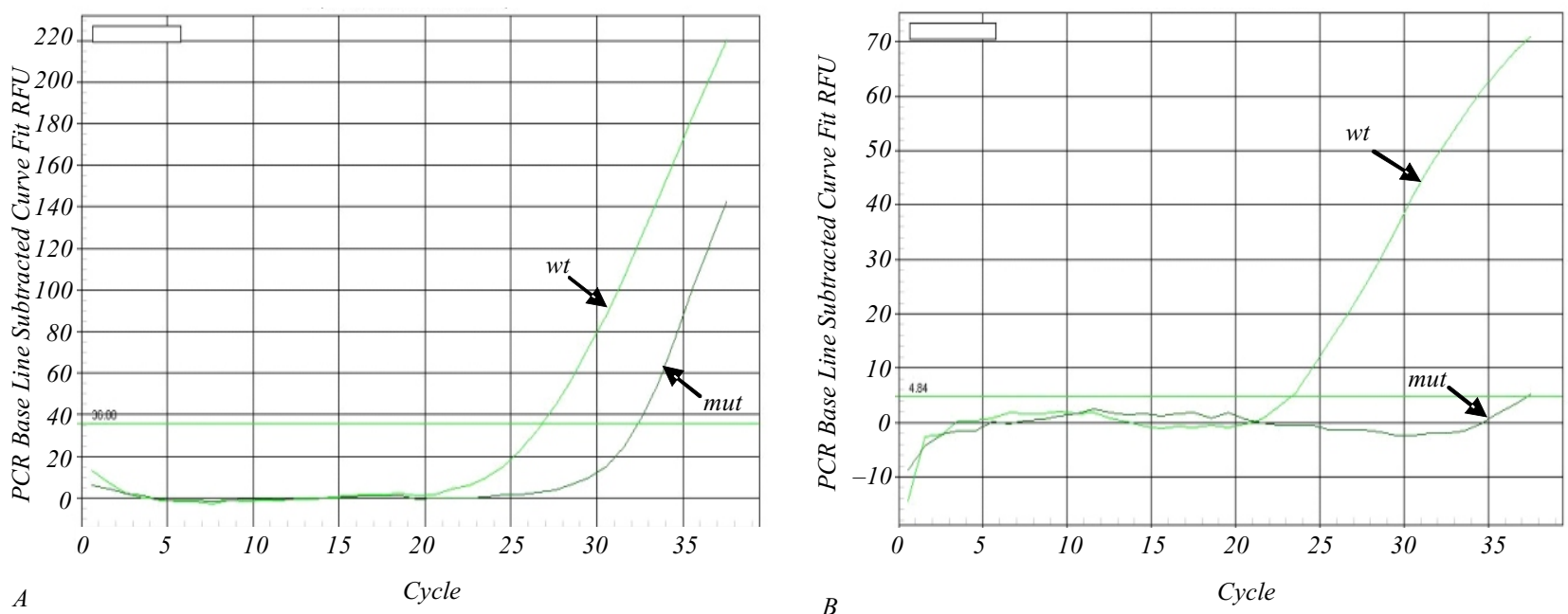

Fig. 2. Fluorogram of the R117H mutation ( $m u t)$ detection in exon 4 of the CFTR gene of the wild type (wt) samples using ARMS Real-Time PCR with the concentration of primers $5 \mathrm{pM}(A)$ - the sample looks like a heterozygous carrier of R117H mutation. Reducing the concentration of primers to $2.5 \mathrm{pM}(B)$ eliminates nonspecific amplification of the mutant product

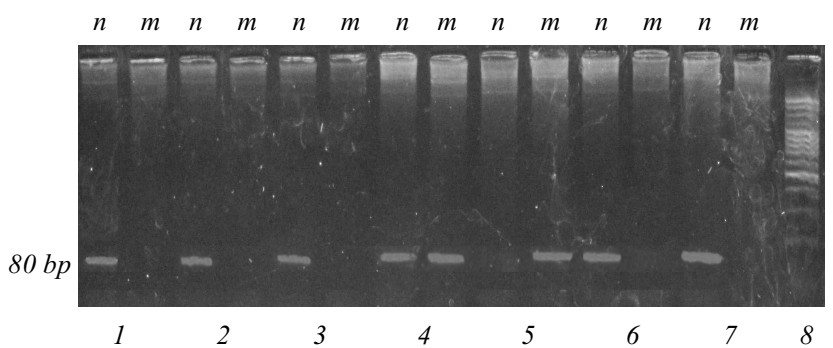

Fig. 3. Electrophoregram of the dF508 ARMS detection in $1.8 \%$ agarose gel:1-3, 6, 7-normal individuals; 4 - heterozygous carrier of the dF508; 5 - homozygous carrier of the dF508; 8 - molecular weight marker (100 bp ladder)

were previously analyzed using RFLP and a heteroduplex assay [8, 10-13].
Results and discussion. To optimize the PCR conditions to avoid non-specific amplification of the alleles we have chosen appropriate concentrations of primers and annealing temperature. Annealing temperature was determined using the gradient PCR (data not shown); the temperature was: for $\mathrm{dF} 508-59{ }^{\circ} \mathrm{C}$; for 2143 delT $-64{ }^{\circ} \mathrm{C}$ and for the mutations $\mathrm{R} 117 \mathrm{H}$, $621+1 \mathrm{G}>\mathrm{T}, \mathrm{W} 1282 \mathrm{X}-67^{\circ} \mathrm{C}$.

It has been shown that the titrating of the concentrations of primers and/or $\mathrm{Mg}^{2+}$ can improve the specificity of the assay [6, 7]. In Fig. 1 the electrophoregram of ARMS PCR assay for the R117H mutation detection with different concentrations of primers is shown. 

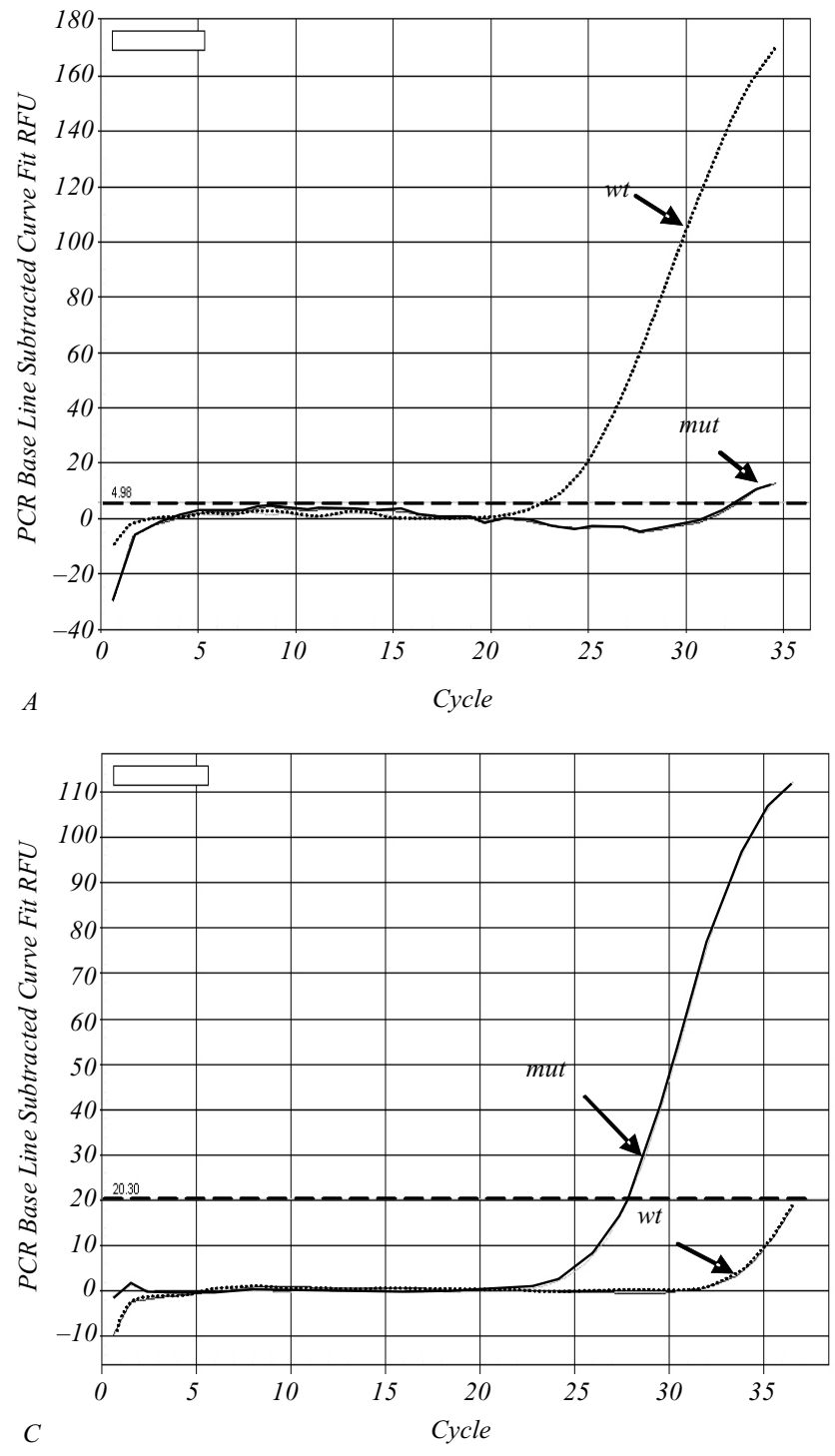

Amplification of the normal samples with the concentration of primers $5 \mu \mathrm{M}$ can lead to the formation of the PCR product with the mutant pair of primers, while the reduction of concentration to $2.5 \mu \mathrm{M}$ prevents from nonspecific amplification.

The influence of the primers concentration on the ARMS specificity is more significant when using RealTime PCR. In Fig. 2 the same experiment for the $\mathrm{R} 117 \mathrm{H}$ mutation is shown.

We have determined the optimal primers concentrations for the developed assay: $\mathrm{dF} 508-6 \mathrm{pM}$ of each primer; R117H - $2.5 \mathrm{pM}$ of each primer; W1282X, $621+1 \mathrm{G}>\mathrm{T}, 2143 \mathrm{delT}-10 \mathrm{pM}$ of each primer. The results of detection of the dF508 deletion using stan-

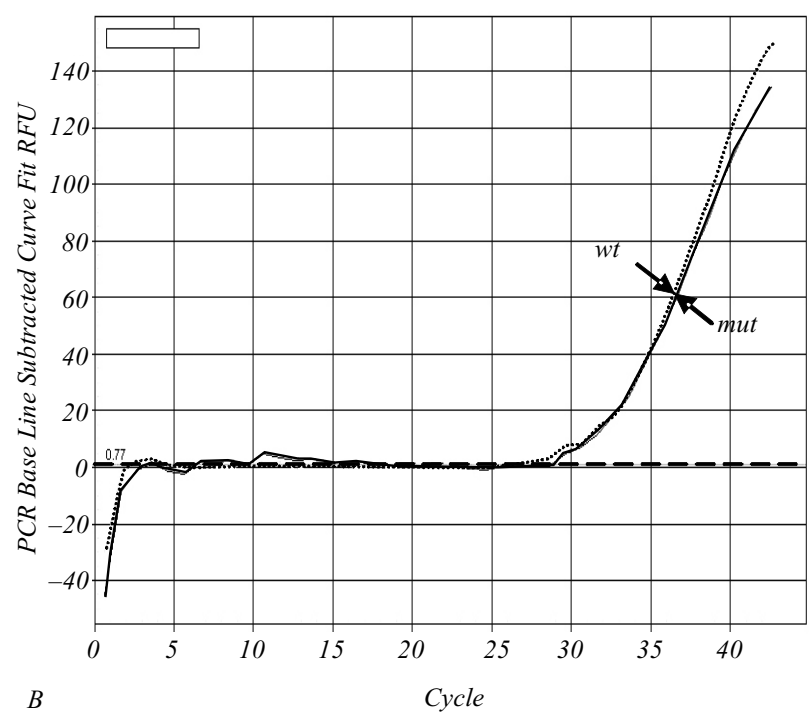

Fig. 4. Fluorogram of the ARMS Real-Time PCR detection of the dF508 mutation (mut): $A$ - the profile of the normal individual (only the wild type ( $w t$ ) sequence amplifies); $B$ the profile of the heterozygous carrier (wild type and mutant sequences amplify with similar effectiveness); $C$ - the profile of the homozygous mutation carrier (only the mutant sequence amplifies)

dard PCR with further agarose gel electrophoresis of the amplified products and Real-Time PCR assay are presented in Fig. 3 and Fig. 4 correspondently.

Considering the optimized annealing temperatures and primers concentrations, the following amplification conditions for detection assays of the dF508, $\mathrm{R} 117 \mathrm{H}, 621+1 \mathrm{G}>\mathrm{T}$, W1282X, 2143delT mutations were proposed:

- concentration of each primer: $\mathrm{dF} 508-6 \mathrm{pM}$; R117H - 2.5 pM; W1282X, 621 + 1 G > T, 2143delT $10 \mathrm{pM}$.

- the cycling conditions for the dF508 mutation were: initial denaturation at $95^{\circ} \mathrm{C}$ for $5 \mathrm{~min}, 30$ cycles consisting of denaturation at $95{ }^{\circ} \mathrm{C}$ for $30 \mathrm{~s}$, annealing 


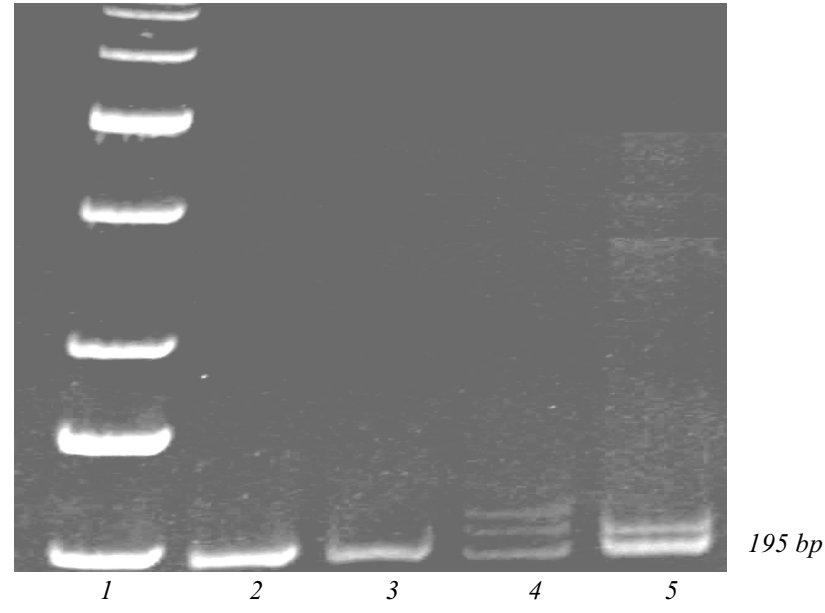

Fig. 5. Electrophoregram of the heteroduplex analysis of exon 13 of the CFTR gene, $10 \%$ PAGE: 1 - molecular weight marker (50 bp ladder); 2, 3 - normal individuals; 4 - heterozygous carriers of

at $59{ }^{\circ} \mathrm{C}$ for $30 \mathrm{~s}$, extension at $72{ }^{\circ} \mathrm{C}$ for $30 \mathrm{~s}$ and a final elongation step at $72{ }^{\circ} \mathrm{C}$ for $3 \mathrm{~min}$.

- the cycling conditions for the $2143 \mathrm{dT}$ mutation were: initial denaturation at $95{ }^{\circ} \mathrm{C}$ for $5 \mathrm{~min}, 30$ cycles consisting of denaturation at $95^{\circ} \mathrm{C}$ for $30 \mathrm{~s}$, annealing at $64{ }^{\circ} \mathrm{C}$ for $30 \mathrm{~s}$, extension at $72{ }^{\circ} \mathrm{C}$ for $30 \mathrm{~s}$ and a final elongation step at $72{ }^{\circ} \mathrm{C}$ for $3 \mathrm{~min}$.

- the cycling conditions for the $\mathrm{R} 117 \mathrm{H}, 621+1 \mathrm{G}>$ $\mathrm{T}, \mathrm{W} 1282 \mathrm{X}$ mutations were: initial denaturation at $95^{\circ} \mathrm{C}$ for $5 \mathrm{~min}, 30$ cycles consisting of denaturation at $95^{\circ} \mathrm{C}$ for $30 \mathrm{~s}$, annealing at $66^{\circ} \mathrm{C}$ for $30 \mathrm{~s}$, extension at $72{ }^{\circ} \mathrm{C}$ for $30 \mathrm{~s}$, and a final elongation step at $72{ }^{\circ} \mathrm{C}$ for $3 \mathrm{~min}$.

- in case of the Real-Time PCR procedure, the cycling conditions were as follows: initial denaturation at $95{ }^{\circ} \mathrm{C}$ for $10 \mathrm{~min}, 35$ two-step cycles consisting of denaturation at $95{ }^{\circ} \mathrm{C}$ for $20 \mathrm{~s}$ and annealing with elongation at $57^{\circ} \mathrm{C}$ (for dF508), $64{ }^{\circ} \mathrm{C}$ (for $2143 \mathrm{dT}$ ) and $67^{\circ} \mathrm{C}$ $(\mathrm{R} 117 \mathrm{H}, 621+1 \mathrm{G}>\mathrm{T}, \mathrm{W} 1282 \mathrm{X})$ for $30 \mathrm{~s}$.

To validate the method developed we have analyzed the control DNA samples with the W1282X $(n=3)$, $\mathrm{R} 117 \mathrm{H}(n=2), 621+1 \mathrm{G}>\mathrm{T}(n=1), 2143 \mathrm{delT}(n=1)$ mutations. For validation of the dF508 ARMS test we have analyzed 100 heterozygous carriers and 50 homozygous carriers of the dF508 mutation. No differences were observed in the results obtained using the standard protocols, except for one control DNA sample with heterozygous dF508 mutation, which as a result of the detailed analysis using the standard sequenced con- trol sample, appeared to be the dI507 mutation, that proves the effectiveness of the developed assay.

For the analysis of 2143 delT mutation we have used the heteroduplex assay to identify the mutant profile for further detection of this deletion with ARMS PCR (Fig. 5) [12, 13]. Using the heteroduplex analysis of the exon 13 CFTR gene we have identified the 2143delT and 2184insA mutations in the control DNA samples. However, application of the heteroduplex analysis for detection of the single-nucleotide deletions/insertions is restricted because of impossibility to detect the mutant homozygote; therefore the ARMS test is preferable.

We have analyzed $48 \mathrm{CF}$ patients, in which one mutation was previously detected, using the developed ARMS assay for the 2143delT mutation and detected 4 heterozygous carriers. The 2184ins A mutation was identified in $12 \mathrm{CF}$ patients using the heteroduplex analysis.

Conclusions. We have developed and, using the analysis of the control DNA samples, validated the diagnostic assays for the detection of common CF mutations: dF508, R117H, $621+1 \mathrm{G}>\mathrm{T}, \mathrm{W} 1282 \mathrm{X}$ and 2143 delT with the ARMS PCR approach. It was shown that the ARMS is a reliable, rapid and inexpensive method and the developed assays can be applied in the standard PCR protocol with further gel-electrophoresis as well as Real-Time PCR with SYBR Green.

\section{О. О. Соловйов, В. М. Пампуха, Л. А. Лівшиць}

Розробка тестів на основі алель-специфічної ПЛР для детекції розповсюджених мутацій у гені трансмебранного регуляторного білка муковісцидозу

Резюме

Мета. Мета дослідження полягала у розробиі діагностичних методик, основаних на приниипі алель-специфічної ПЛР для аналізу розповсюджених мутаиій в гені ТРБМз використанням двох підходів: традиційної ПЛР з подальшим розділенням продуктів у гель-електрофорезі та з використанням ПЛР у реальному часі. Методи. Для дослідження обрано такі мутаціїdF508, W1282X, R117H, $621+1 G>T, 2143$ delT з частотою зустрічальності в Україні: dF508 - 43,3\%; 2143 delT-1,38\%; W1282X-1,1\%; R117H i $621+1 G>T-<0,6 \%$. Використано контрольні зразки ДНК з відповідними мутаціями, ідентифіковані методами гетеродуплексного аналізу та ПДРФ. Результати. Проведено дизайн та оптимізовано умови алель-спеиифічної ампліфікачії для вивчення мутачій dF508, W1282X, $R 117 H, 621+1 G>T, 2143$ delT. Розроблені методики аналізу підтверджено перевіркою контрольних зразків ДНК з мутаиіями $W 1282 X(n=3), R 117 H(n=2), 621+1 G>T(n=1)$, 
2143 delT $(n=1)$. Щоб перевірити тест на dF508 нами проаналізовано 100 носіїв даної мутаиії в гетерозиготному стані та 50 - в гомозиготному. За допомогою створеної методики детекції 2143 delТ проаналізовано також 48 пацієнтів, хворих на муковісцидоз, у яких первинно виявлено лише по одній мутаціі разом з невідомим мутантним варіантом. В результаті аналізу серед них визначено ще чотири носії зазначеної делеції в гетерозиготному стані. При иьому не встановлено розбіжностей в даних, отриманих з використанням стандартних протоколів аналізу досліджених мутацій. Висновки. Показано, шчо метод алель-специфічної ПЛР є швидким та відносно недорогим, його можна застосовувати для детекиії відомих мутаиій у гені ТРБМ.

Ключові слова: алель-специфічна ПЛР, ПЛР у реальному часі, муковісиидоз, ген ТРБМ

\section{А. А. Соловьев, В. Н. Пампуха, Л. А. Ливщиц}

Разаработка тестов на основе аллель-специфической ПЦР для детекции распространенных мутаций в гене трансмебранного регуляторного белка муковисцидоза

Резюме

Цель. Цель работы состояла в разработке диагностических методик, основанных на принципе аллель-специфической ПЦР для анализа распространенных мутаций в гене ТРБМ с использованием двух подходов: традиционной ПЦР с дальнейчим разделением продуктов в гель-электрофорезе и ПЦР в реальном времени. Методы. Для исследований выбраны следуюшие мутаичи - dF508, W1282X, R117H, 621 + 1G>T, 2143delT c чаcтотой встречаемости в Украине: dF508 - 43,3\%; $2143 \mathrm{delT}$ $1,38 \%$; W1282X-1,1\%; R117H u $621+1 G>T-<0,6 \%$. Использованы контрольные образиы ДНК с соответствующими мутациями, идентифииированные методами гетеродуплексного анализа и ПДРФ-анализа. Результаты. Проведен дизайн и оптимизированы условия аллель-специфической амплификации для анализа мутаџий dF508, W1282X, R117H, $621+1 G>T, 2143$ delT. Разработанные методики анализа подтверждены проверкой контрольных образцов ДНК с мутациями W1282X $(n=3), R 117 H(n=2), 621+1 G>T(n=1), 2143$ delT $(n=1)$. Для проверки теста на dF508 проанализированы 100 носителей данной мутаиии в гетерозиготном состоянии и 50 в гомозиготном состоянии. С помощьью разработанной методики детекиии 2143delT проанализированы также 48 пациентов, больных муковисиидозом, у которых первично выявлено лишь по одной мутации вместе с неизвестным мутантным вариантом. В результате анализа среди них определены еще четырее носителя указанной делеции в гетерозиготном состоянии. При этом не найдено отличий в данных, полученных с использованием стандартных протоколов анализа этих мутаций. Выводы. Показано, что метод аллель-специфической ПЦР является быстрым и относительно недорогим, его можно применять для детекции известных мутациии в гене ТРБМ.

Ключевые слова: аллель-специфическая ПЦР, ПЦР в реальном времени, муковисцидоз, ген ТРБМ.

\section{REFERENCES}

1. Kerem B.-S., Rommens J. M., Buchanan D. M., Cox T. K., Chakravarti A., Buchwald M., Tsui L.-C. Identification of the cystic fibrosis gene: genetic analysis // Science.-1989.-245, N 4922.-P. 1073-1080.

2. Tsui L. C. Cystic fibrosis mutation database: www.genet.sickkids.com.ca.

3. Newton C. R., Graham A., Heptinstall L. E., Powell S. J., Summers C., Kalsheker N., Smith J. C., Markham A. F. Analysis of any point mutation in DNA. The amplification refractory mutation system (ARMS) // Nucl. Acids Res.-1989.-17, N 7.-P. 2503-2516.

4. Okayama H., Curiel D. T., Brantly M. L., Holmes M. D., Crystal R. D. Rapid nonradioactive detection of mutations in the human genome by allele-specific amplification // J. Lab. Clin. Med.-1989.-114, N 2.-P. 105-113.

5. Sommer S. S., Groszbach A. R., Bottema C. D. PCR amplification of specific alleles (PASA) is a general method for rapidly detecting known singlt-base changes // Biotechniques.-1992.-12, N 1.-P. 82-87.

6. Patrinos G. P., Ansorge W. Molecular diagnostics.-Amsterdam: Elsevier, 2005.-461 p.

7. Ferrie R. M., Schwarz M. J., Robertson N. H., Vaudin S., Super M., Malone G., Little S. Development, multiplexing and application of ARMS tests for common mutations in the CFTR gene // Amer. J. Hum. Genet.-1992.-51, N 2.-P. 251262.

8. Livshits L. A., Kravchenko S. A., Mikhaylets L. P., Sopko N. I. Mutation screening results // Eur. Com. Concer. Act. Cystic Fibrosis Newsletter.-1996.-3, N 2.-P. 3-4.

9. Maniatis T., Fritsch E. F., SambrookJ. Molecular cloning: A laboratory manual.-New York: Cold Spring Harbor Lab. publ., 1982.-545 p.

10. Livshyts L. A. A molecular genetic analysis of the mutations in the exons of the CFTR gene in cystic fibrosis patients in Ukraine // Cytology and Genetics.-2000.-34, N 4.-P. 6-9.

11. Livshits L. A., Kravchenko S. A., Grishko V. I., Musienko S. I., Ekshyyan O. Yu., Sopko N. I. Prenatal diagnosis of the most common monogenic hereditary diseases in Ukraine // Cytogenet. Cell. Genet.-1997.-77.-P. 157.

12. Ivaschenko T. E., Baranov V. S. Biochemical and moleculargenetic basics of cystic fibrosis pathogenesis.-St.-Petersburg: Intermedika, $2002-256 \mathrm{p}$.

13. Petrova N. V., Kapranov N. I., Ginter E. K. Detection of frequent mutations of the CFTR gene in cystic fibrosis patients from Central Russia // Genetika.-1997.-33, N 1.-P. 106109.
UDC $575.11+577.21$

Recieved 12.04.10 